World Petroleum Resources Project

\title{
Assessment of Undiscovered Oil and Gas Resources of the South Africa Coastal Province, Africa
}

\begin{abstract}
The South Africa Coastal Province along the South Africa coast recently was assessed for undiscovered, technically recoverable oil, natural gas, and natural gas liquids resources as part of the U.S. Geological Survey's (USGS) World Oil and Gas Assessment. Using a geology-based assessment methodology, the USGS estimated mean volumes of 2.13 billion barrels of oil, 35.96 trillion cubic feet of natural gas, and 1,115 million barrels of natural gas liquids.
\end{abstract}

\section{Introduction}

The main objective of the U.S. Geological Survey's (USGS) World Petroleum Resources Project is to assess the potential for undiscovered, technically recoverable oil and natural gas resources of the world, exclusive of the United States. As part of this program, the USGS recently completed an assessment of the South Africa Coastal Province (fig. 1), an area of about 367,550 square kilometers $\left(\mathrm{km}^{2}\right)$ that covers part of the southern offshore and onshore of South Africa. This assessment was based on data from oil and gas exploration wells and published geologic reports.

The basic geologic framework of the offshore part of the South Africa Coastal Province developed in two phases: (1) a syn-rift phase that was initiated during the Jurassic and continued into the Lower Cretaceous and resulted in the formation of grabens and half-grabens, and (2) a transform-drift-passive margin phase that began in the late Albian and continues to the present. The total thickness of the Mesozoic to Cenozoic stratigraphic section is more than 5,000 meters $(\mathrm{m})$ on the outer parts of the continental shelf (fig. 2).

The South Africa Coastal Province was assessed for the first time because of increased interest in its future potential. The assessment was geology based and used the total petroleum system (TPS) concept. The geologic elements of a TPS include hydrocarbon source rocks (source rock maturation and hydrocarbon generation and migration), reservoir rocks (quality and distribution), and traps for hydrocarbon accumulation. Using these geologic criteria, the USGS defined the Mesozoic Composite TPS with one assessment unit (AU), the Mesozoic-Cenozoic Reservoirs AU (fig. 1), encompassing 212,652 $\mathrm{km}^{2}$ that includes the offshore part of the province to a water depth of $4,000 \mathrm{~m}$. The TPS was defined to include Middle to Upper Jurassic lacustrine source rocks containing 1.0 to 3.7 weight percent total organic carbon (TOC) and Cretaceous marine source rocks, including Aptian strata containing Type II kerogen ranging from 2.0 to 4.3 weight percent TOC and the Cenomanian-Turonian strata containing Type II kerogen ranging from 1.0 to 3.0 weight percent TOC.

The Mesozoic-Cenozoic Reservoirs AU contains Cretaceous and lower Paleogene clastic reservoirs and traps that mostly are associated with growth fault-related structures, rotated fault blocks within the continental shelf, deep water fans, turbidite channels and sandstones, slope truncations along the present-day shelf and paleoshelf edge, and Cretaceous and Paleogene stratigraphic pinch-outs along the southern AU margin. Possible Jurassic and Lower Cretaceous syn-rift reservoirs are associated with the grabens and half grabens in the deeper parts of the offshore. The primary seals are Cretaceous and Paleogene marine mudstones and shales. At the time of the assessment, only 183 exploration wells had been drilled since 1969 , resulting in the discovery of 7 oil and 17 gas accumulations exceeding the minimum size of 5 million

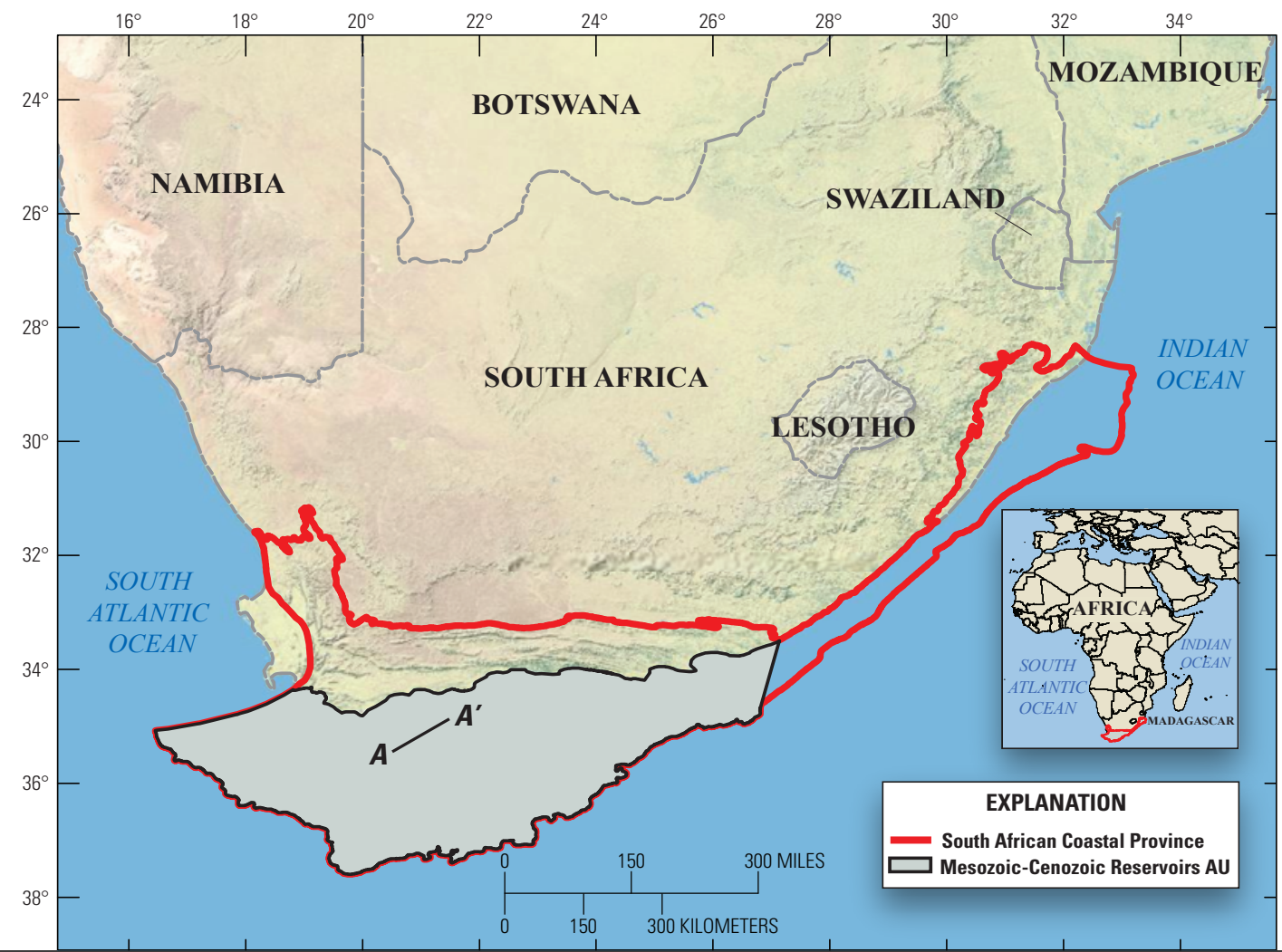

Figure 1. Locations of the South Africa Coastal Province and MesozoicCenozoic Reservoirs Assessment Unit (AU), South Africa. Cross section shown in figure 2. 
barrels of oil equivalent and 30 billion cubic feet of gas. The AU is considered to be underexplored for its size.

Exploration wells and discovered accumulations on the continental shelf and upper slope (IHS Energy, 2009) provide evidence for (1) the existence of an active petroleum system containing Cretaceous marine source rocks that have produced hydrocarbons most likely since the Late Cretaceous, and (2) the migration of hydrocarbons into Cretaceous and Paleogene reservoirs.

\section{Resource Summary}

Using a geology-based assessment, the USGS estimated mean volumes of undiscovered, technically recoverable conventional oil and gas resources for the Mesozoic-Cenozoic Reservoirs AU in the South Africa Coastal Province at 2,129 million barrels of oil (MMBO), 35,964 billion cubic feet of gas (BCFG), and 1,115 million barrels of natural gas liquids (table 1). The estimated mean size of the largest oil field that is expected to be discovered is $340 \mathrm{MMBO}$, and the estimated mean size of the expected largest gas field is 2,937 BCFG. For this assessment, a minimum undiscovered field size of 5 million barrels of oil equivalent (MMBOE) was used. No attempt was made to estimate economically recoverable reserves.

\section{References Cited}

Davies, C.P.N., 1997, Hydrocarbon evolution of the Bredasdorp Basin, offshore South Africa-From source to reservoir: Stellenbosch, South Africa, University of Stellenbosch, Ph.D. dissertation, 1123 p.

IHS Energy, 2009, International petroleum exploration and production database [current through December 2009]: Available from IHS Energy, 15 Inverness Way East, Englewood, CO 80112 USA.

\section{For Additional Information}

Assessment results are available at the USGS Central Energy Resources Science Center website: http:/energy.cr.usgs.gov/oilgas/ noga/ or contact Michael E. Brownfield, the assessing geologist (mbrownfield@usgs.gov).

\section{Offshore South Africa Province Assessment Team}

Michael E. Brownfield, Christopher J. Schenk, Ronald R. Charpentier, Timothy R. Klett, Troy A. Cook, and Richard M. Pollastro.

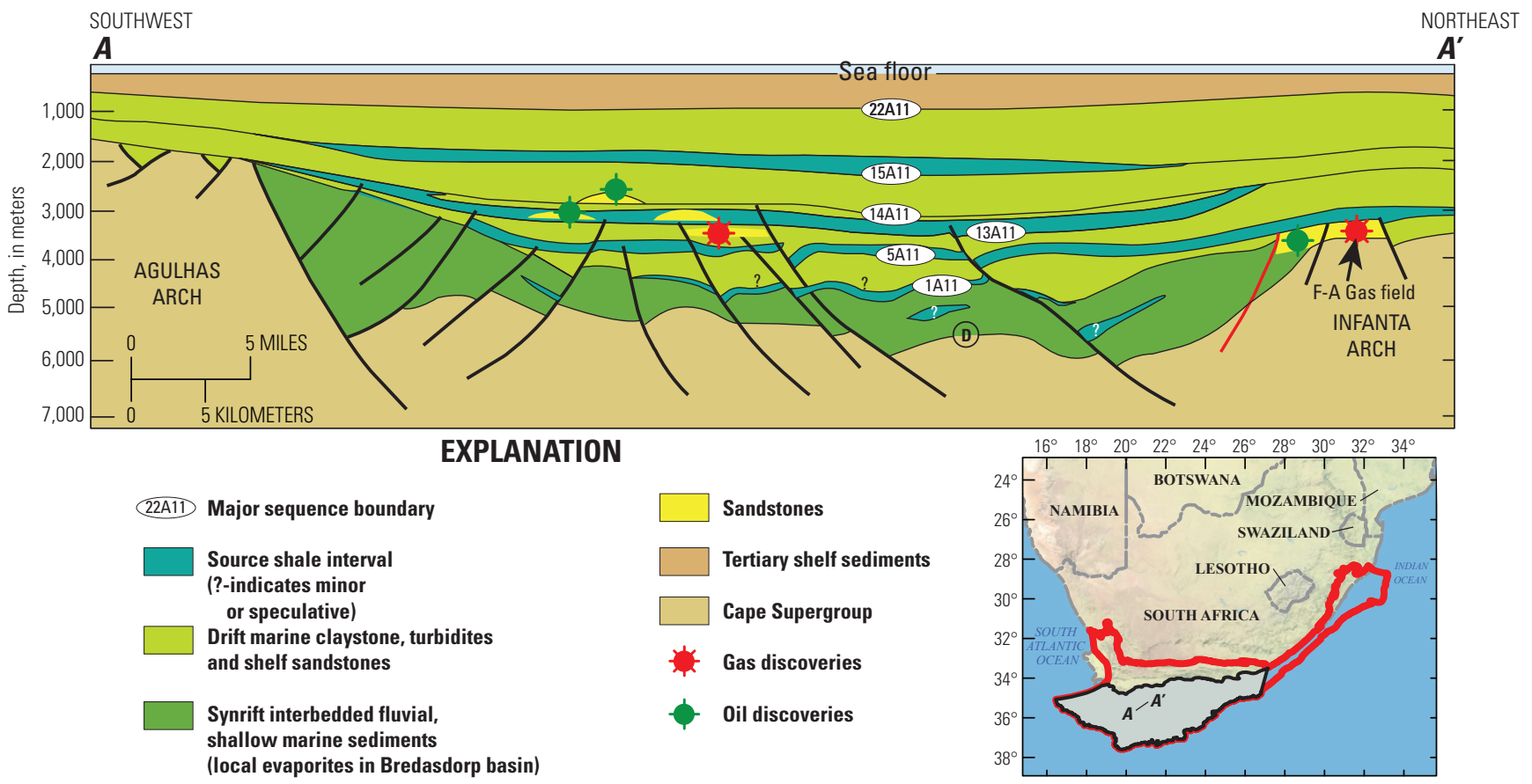

Figure 2. Southwest to northeast schematic cross section showing major faults, hydrocarbon discoveries, source rocks, and major sequence boundaries in the Bredasdorp Basin. Modified after Davies (1997).

Table 1. South Africa Coastal Province assessment results for undiscovered, technically recoverable oil, gas, and natural gas liquids.

[Largest expected mean field size in million barrels of oil and billion cubic feet of gas; MMBO, million barrels of oil; BCFG, billion cubic feet of gas; MMBNGL, million barrels of natural gas liquids. Results shown are fully risked estimates. For gas accumulations, all liquids are included as natural gas liquids (NGL). Undiscovered gas resources are the sum of nonassociated and associated gas. F95 represents a 95-percent chance of at least the amount tabulated; other fractiles are defined similarly. AU, assessment unit; AU probability is the chance of at least one accumulation of minimum size within the AU. TPS, total petroleum system. Gray shading indicates not applicable]

\begin{tabular}{|c|c|c|c|c|c|c|c|c|c|c|c|c|c|c|}
\hline \multirow{3}{*}{$\begin{array}{l}\text { Province, total petroleum } \\
\text { systems (TPS) and } \\
\text { assessment units (AU) }\end{array}$} & \multirow{3}{*}{$\begin{array}{c}\text { Field } \\
\text { type }\end{array}$} & \multirow{3}{*}{$\begin{array}{c}\text { Largest } \\
\text { expected } \\
\text { mean } \\
\text { field size }\end{array}$} & \multicolumn{12}{|c|}{ Total undiscovered resources } \\
\hline & & & \multicolumn{4}{|c|}{ Oil (MMBO) } & \multicolumn{4}{|c|}{ Gas (BCFG) } & \multicolumn{4}{|c|}{ NGL (MMBNGL) } \\
\hline & & & F95 & F50 & F5 & Mean & F95 & $\mathrm{F} 50$ & F5 & Mean & F95 & F50 & F5 & Mean \\
\hline \multirow{2}{*}{$\begin{array}{l}\text { Mesozoic-Cenozoic } \\
\text { Reservoirs AU }\end{array}$} & Oil & 340 & 924 & 1,984 & 3,851 & 2,129 & 1,209 & 2,728 & 5,657 & 2,995 & 32 & 74 & 155 & 81 \\
\hline & Gas & 2,937 & & & & & 15,915 & 30,931 & 57,024 & 32,969 & 496 & 968 & 1,794 & 1,034 \\
\hline
\end{tabular}

